\title{
The Role of Intellectual Capital on Financial Performance of SMEs
}

\author{
Sylvia Christina Daat ${ }^{*}$, Mariolin A. Sanggenafa, Rudiawie Larasati \\ Faculty of Economics and Business, Universitas Cenderawasih, Indonesia
}

Received August 11, 2021; Revised October 17, 2021; Accepted October 27, 2021

\section{Cite This Paper in the following Citation Styles}

(a): [1] Sylvia Christina Daat, Mariolin A. Sanggenafa, Rudiawie Larasati , "The Role of Intellectual Capital on Financial Performance of SMEs," Universal Journal of Accounting and Finance, Vol. 9, No. 6, pp. 1312 - 1321, 2021. DOI: 10.13189/ujaf.2021.090610.

(b): Sylvia Christina Daat, Mariolin A. Sanggenafa, Rudiawie Larasati (2021). The Role of Intellectual Capital on Financial Performance of SMEs. Universal Journal of Accounting and Finance, 9(6), 1312 - 1321. DOI: 10.13189/ujaf.2021.090610.

Copyright $\bigcirc 2021$ by authors, all rights reserved. Authors agree that this article remains permanently open access under the terms of the Creative Commons Attribution License 4.0 International License

\begin{abstract}
The purpose of this study was to obtain empirical evidence of the influence of components of intellectual capital, namely human capital, structural capital, and relational capital on the financial performance of small medium enterprises or SMEs in Jayapura City and Jayapura Regency, West Papua, Indonesia. Respondents in this study consisted of 54 respondents who had business fields, consisting of culinary businesses, fashion, daycare services, lodging services, and futsal fields. In addition, respondents are selected based on ethnicity, namely, Papuan as many as 26 people or $51.8 \%$ and non-Papuan as many as 28 people or $48.2 \%$. The analytical tool is used in SmartPLS 3 by looking at the measurements of the outer model and inner model. The results show that the components of human capital and relational capital significantly affect the financial performance of SMEs with a significance value of 0.042 and 0.044 , respectively. Meanwhile, the hypothesis of the influence of the structural capital component on SME financial performance is not statistically supported with a significance value of 0.569 . The results theoretically provide empirical evidence for studies on the importance of intellectual capital on the financial performance of SMEs in particular with the context of SMEs in Papua that has not been studied. The main findings of this study highlight the development of intellectual capital in SMEs. The limitations of this study lie in the effect of structural capital components on financial performance which is not empirically supported. Thus, further research needs to examine the effect of structural capital interaction with other components of intellectual capital to improve MSME financial
\end{abstract}

performance.

Keywords Human Capital, Structural Capital, Customer Capital, MSMEs, Financial Performance

\section{Introduction}

In the last two to three decades, the world has moved into the information age. The economy has shifted from an industry-based economy to a knowledge-based economy. In this knowledge-based economy, intangible assets such as intellectual capital are more important for value creation than physical assets [1]. Intellectual capital is seen as having a very important role in creating and maintaining competitive advantage and subsequently the company's performance and value [2-5].

Intellectual capital is one of the non-physical resources or intangible assets that is not visible in the company's statement of financial position, but is increasingly recognized as a strategic asset and is seen as important for companies in increasing value and sustainable competitive advantage [4-6]. Since the early 1990s, research related to intellectual capital has used many definitions and terms to describe intellectual capital or intangible assets. Intellectual capital is defined as the sum of components that can add value to the company. Intellectual capital is the possession of knowledge and experience, professional knowledge and skills, good relationships, and technological capacity, which when applied will give the 
organization a competitive advantage [7]. Intellectual capital is not only related to the knowledge and skills of employees, but also includes company infrastructure, customer relations, information systems, technology, and the ability to innovate and react.

This research was conducted to obtain empirical evidence of the influence of intellectual capital consisting of human capital, structural capital, and relational capital on the performance of micro, small and medium enterprises (MSMEs) in Jayapura City and District. MSME actors in Jayapura City continue to increase every year, especially OAP (indigenous Papuans) entrepreneurs and more specifically female OAP entrepreneurs who account for $60 \%$ of the total MSME actors registered in the Cooperative and SME Office (Disperindagkop) in Jayapura City. It is interesting to study to find out the use of intellectual capital to improve the competitive ability of these business actors in the current information age.

In this study, testing will also be carried out to obtain empirical evidence that component of intellectual capital has the greatest influence on the financial performance of MSMEs. This additional test was carried out because several previous research results found that human capital is the main determinant of SME (small medium enterprise) performance compared to structural capital and relational capital [8]. The reason is that small and medium enterprises are constrained by size and funds to make large investments in external resources. Therefore, the internal knowledge possessed by MSME managers and employees, in this case human capital, must be managed and used effectively and efficiently so that MSMEs can maintain their success. Thus, this study aims to empirically examine the effect of human capital on the financial performance of SMEs, structural capital on the financial performance of SMEs, relational capital on the financial performance of MSMEs, and the most influential component of intellectual capital on the financial performance of MSMEs.

\section{Literature Review}

Resources based theory is the company's resources as the main controller behind the company's performance and competitiveness $[9,10]$. Based on this RBT, an organization can be assessed as a collection of physical resources, human resources, and organizational resources [11]. Resource Based Theory is a theory that develops in strategic management and competitive advantage in companies that believe that companies will achieve excellence if they have reliable resources. This theory refers to the advantages of companies if they have superior resources. With superior resources, the company will have a competitive advantage compared to other companies $[12,13]$.

Resources Based Theory discusses the resources owned by the company and how the company can process and utilize its resources. The company's ability to manage its resources properly can create competitive advantage so that it can create value for the company. In order to compete in today's modern economic conditions, organizations need two main things. First, it has advantages in its resources, both in the form of tangible and intangible assets. The second is the ability to manage its resources effectively.

Moreover, the term intellectual capital was first coined by Galbraith [14]. There are various definitions of intellectual capital from several experts [15]. According to the Chartered Institute of Management Accountant (CIMA), intellectual capital is knowledge and experience, professional abilities, good relations, and cooperation, as well as technological capacity [16]. Intellectual capital is a source of knowledge in the form of employees, customers, processes, or technology, which companies can use for value creation processes $[2,17,18]$. Intellectual capital is a knowledge-based asset in a company which is the basis of a company's core competencies that can affect its resilience and competitive advantage [19].

In various studies from various disciplines, researchers identify intellectual capital or intangible assets, as all resources, properties, and attributes, or as non-monetary assets that can generate future value or benefits [20]. From some definitions, it can be shown that as a concept, intellectual capital refers to intangible assets or non-physical capital or intangible capital related to knowledge, technology, employees, process management within the company which is the company's competitive advantage and useful in operational activities as well as company value creation. In general, researchers identify three main constructs of intellectual capital, namely: human capital, structural (organizational) capital, and relational capital [21].

Human capital is a component of intellectual capital that includes various knowledge, skills, abilities, experience, intelligence, creativity, and motivation possessed by individuals within a company or organization [22]. Human capital as a capital is a life hood in intellectual capital. This is the source of innovation and improvement, but it is a component that is difficult to measure. Human capital is also a source of very useful knowledge, skills, and compensation in an organization or company. Human capital reflects the company's collective ability to produce the best solutions based on the knowledge possessed by the people in the company. Human capital will increase if the company is able to manage the knowledge it has [23].

Structural capital or organizational capital as organizational capital is the ability of an organization or company to fulfill the company's routine processes and structures that support employees' efforts to produce optimal intellectual performance and overall business performance $[24,25]$, for example company operational systems, manufacturing processes, organizational culture, management philosophy, and all forms of intellectual 
property owned by the company. An individual can have a high intellectual level, but if the organization has poor systems and procedures, then intellectual capital cannot achieve optimal performance and the existing potential cannot be utilized optimally. Lastly, relational capital is a component of intellectual capital that provides real value. Relational capital is a harmonious relationship that is owned by the company with its partners, both from reliable and quality suppliers, from consumers who are loyal and satisfied with the company's services, from the company's relationship with the government, as well as with the surrounding community [26, 27]. Good management of relational capital will cause competence in organizational activities or responses to market changes to be developed.

Saint-Onge [28] defines relational (customer) capital as the depth (penetration), breadth (coverage), and relationship (loyalty) of the company. Edvinsson \& Malone [29] added that customer capital is the tendency of a company's customers to continue doing business with the company. Customer capital appears in the form of a learning process, access, and trust [30]. When a company or a person decides to buy from a company, the decision is based on the quality of their relationship, price, and technical specifications [31]. The better the relationship, the more likely the planned purchase will occur, and this means the greater the chance that the planned purchase will occur, and the greater the opportunity for the company to learn with and from its customers and suppliers [18].

Furthermore, performance is a quantitative and qualitative measure that describes the level of achievement of a goal or goal that has been set by the organization [32]. Performance is a series of management activities that provide an overview of the extent to which the results have been achieved in carrying out their duties and responsibilities in the form of public accountability in the form of successes or deficiencies that occur. The achievement of the results of a series of activities in question includes standard work results, targets or targets, or criteria that have been determined since the start of the business [31]. Performance is a series of management activities that provide an overview of the extent to which the results have been achieved in carrying out their duties and responsibilities in public accountability, both in the form of successes and shortcomings that occur [33]. Performance is the most important indicator of success and this is proven both in real terms and theoretically. In other words, performance in the organization is the answer to the success or failure of the organizational goals that have been set [34]. The notion of performance or performance is the work that can be achieved by a person or group of people in a company under their respective authorities and responsibilities to achieve company goals. Legally, it does not violate the lawor conflict with morals and ethics. Performance can be defined as the level of achievement of results or the level of achievement of organizational goals [35].

\section{Hypothesis Development}

Human capital is defined as the knowledge, skills, and experience that a person has when managing a business $[36,37]$. Some of this knowledge is unique to each individual, and some are general, such as a capacity for innovation, creativity, knowledge, and experience, learning capacity, loyalty, formal education, and education [38]. Human capital is also a combination of genetic inheritance, education, experience, and attitudes about life and business. The experience possessed by individuals will improve performance in a business because with experience a person will act quickly when there is a problem in his business. In addition, the existence of training and education will add insight in becoming an MSME entrepreneurs [39].

Structural capital is defined as knowledge that will remain in entrepreneurship [40-42]. Structural capital consists of organizational routines, procedures, systems, culture, and databases [43]. Some of the structural capital is protected by law and becomes intellectual property right, which is legally owned by the company. In this regard, structural capital has two objectives to achieve. The first is to codify transferable knowledge. This is done so that the system is not lost. In the business world, structural capital is associated with operational systems and organizational culture. A good system and prioritizing the Value for Money aspect will improve the financial performance of MSMEs. In addition, organizational culture becomes an identity and character of a place of business that will be known by the public. A good organizational culture will improve the image of MSMEs and improve performance [44].

Relational capital is a harmonious relationship or so-called association network owned by the company and its partners, both from reliable and quality suppliers, from loyal customers and satisfied with the services of the company concerned, from the company's relationship with the government and with the surrounding community $[18$, 45]. Customer capital can arise from various parts outside the company environment which can add value to the company. With company values that have a positive impact on partners, cooperation will be maintained, business continuity will last a long time so that it will improve the financial performance of MSMEs [5, 46]. Based on the explanation above, the hypothesis of this research is as follows:

H1: Human Capital significantly affects MSME financial performance

H2: There is a significant effect of structural capital on MSME financial performance

H3: Relational Capital has a significant effect on MSME financial performance 


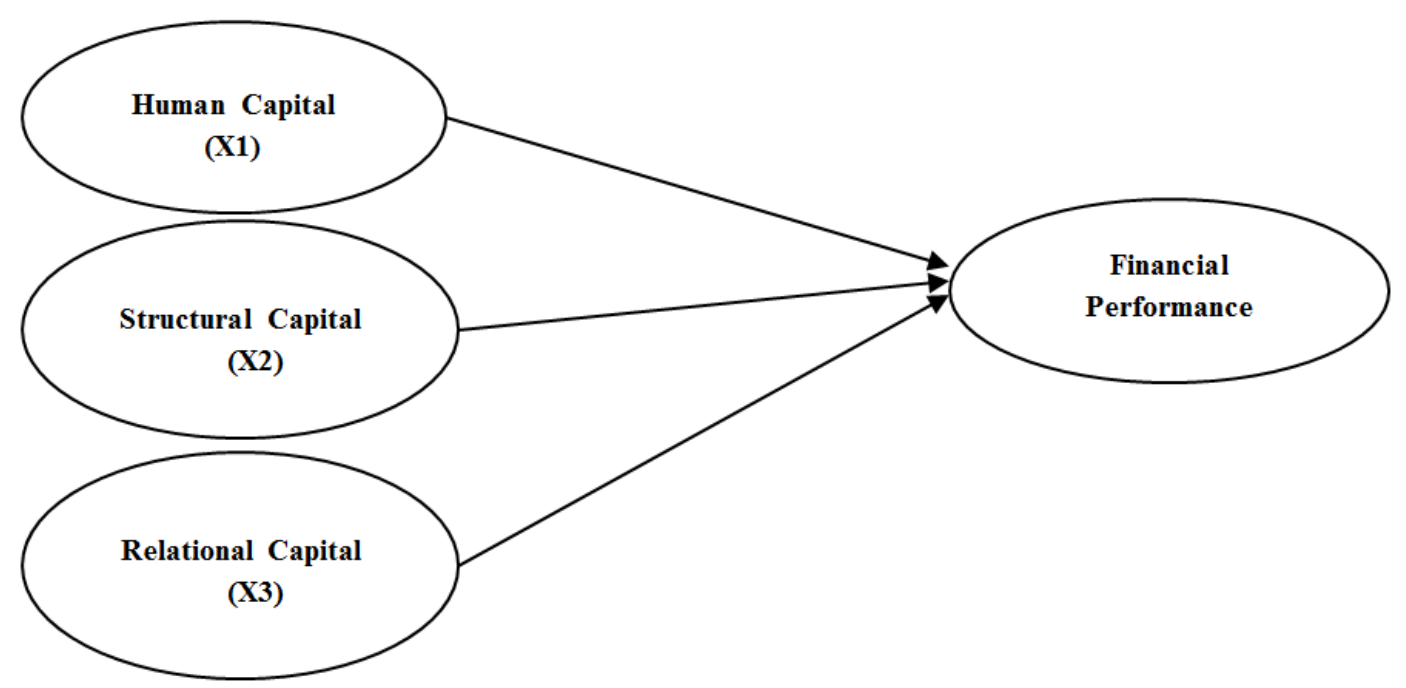

Figure 1. Research model

\section{Research Methods}

This type of research is designed as causal research with a quantitative approach. Causal research is useful for measuring the relationship between research variables, or for analyzing the effect of one variable on other variables. This study is designed to provide empirical evidence and analyze the role of Intellectual Capital in the form of Human Capital, Structural Capital, and Relational Capital on MSME financial performance in the City and District of Jayapura.

The population used in this study are micro, small, and medium enterprises in the City and District of Jayapura which are registered with the Disperindagkop and MSMEs. The sample was selected using a random sampling technique, while the sampling design used in this study was unrestricted random sampling. The reason for using unrestricted random sampling is that this sampling design has a small bias and can be more generalized [47].

The type of data used in this study is quantitative data, which is data in the form of numbers or numbers. This study uses primary data. Primary data were obtained directly from respondents, namely MSME actors in Jayapura City and Regency through filling out a questionnaire that the researchers gave.

The dependent variable used in this study is the MSME financial performance variable, which is the final result of each activity, process, or organizational unit including financial and non-financial business performance. The performance variable was measured using an instrument that was tested in Canada and then retested in Malaysia
$[15,48]$. This questionnaire consists of ten statements. Human capital in this study is the knowledge of individuals in the organization described by their employees, including experience, skills, motivation, and tolerance for ambiguity and so on, which are generated through competence, attitude, and intellectual intelligence. Structural Capital in this study refers to a collection of non-human knowledge in an organization including databases, organizational structure, process guidelines, strategies, routines, software, hardware, and anything else whose value in the company is greater than its material value. The relational capital in this study is knowledge formed in marketing channels and the company's external relationships with consumers, suppliers, government, industry associations, and so on [49].

The statements in this questionnaire are filled in to the extent to which the respondents agree with the Likert scale $(1=$ strongly disagree to $5=$ strongly agree $)$. The use of the five-point Likert scale is a reduction from the Likert scale used a seven-point Likert scale, while in this study a five-point Likert scale was used to make it easier for respondents to answer questions.

\section{Results}

The results of field studies conducted on SMEs in Jayapura City and Regency amounted to 54 respondents. The characteristics of respondents in this study are shown in Figure 2. 


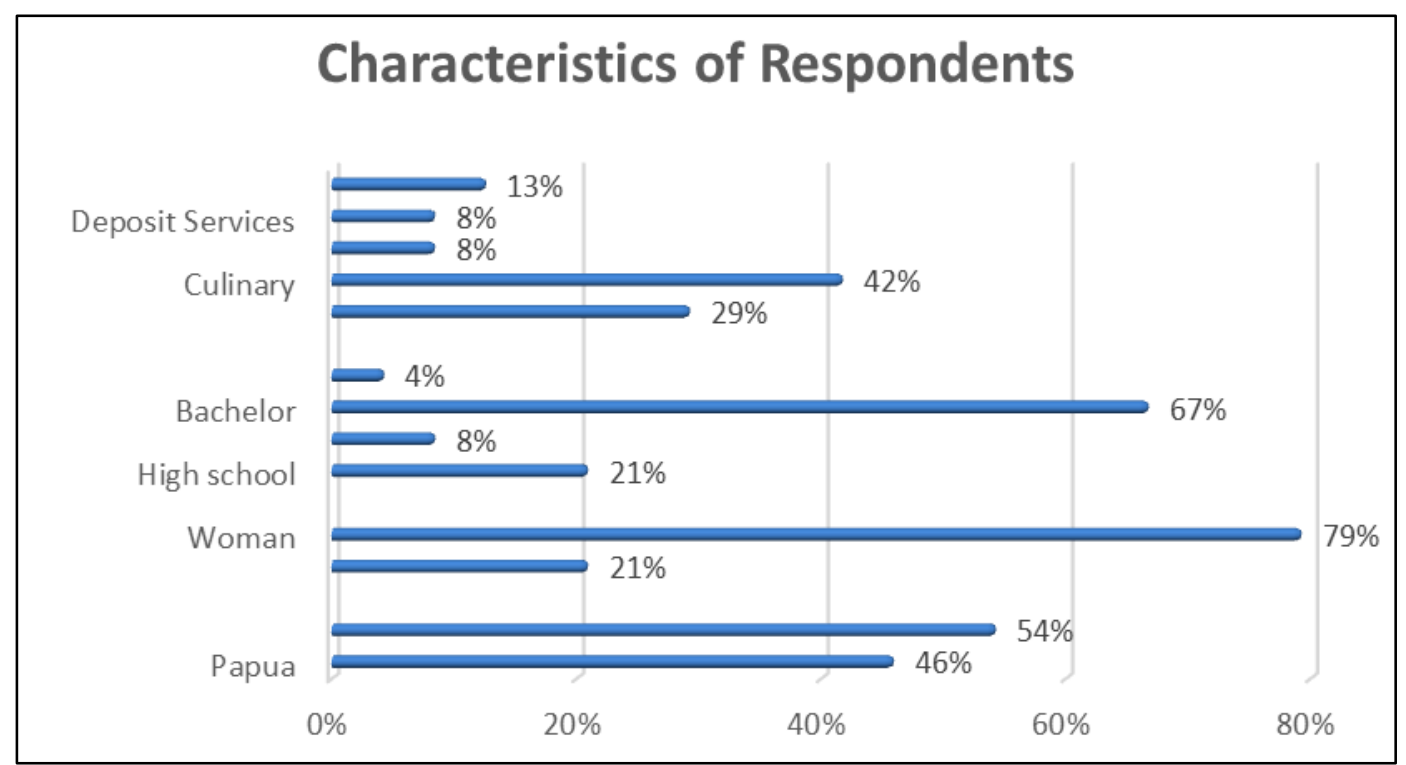

Figure 2. Respondent Characteristics

Based on Figure 2, it is explained that the characteristics of the respondents consist of the type of business, educational background, gender, and ethnic origin. The type of business that has the highest percentage is in the culinary business by $42 \%$. Educational background with undergraduate level is $67 \%$. Most respondents, in terms of gender, are women, accounting for $79 \%$. Based on ethnic groups, non-Papua accounts for $54 \%$ and Papua $46 \%$.

A convergent validity test is carried out to determine the validity of an indicator used. The indicator is declared valid with a weight or loading factor value above 0.50 . In this Convergent Test, several indicators are declared invalid so that they must be eliminated from the number of existing indicators, namely the HC2 indicator. The results of retesting for the outer model after the issuance of several indicators are presented in Figure 3.

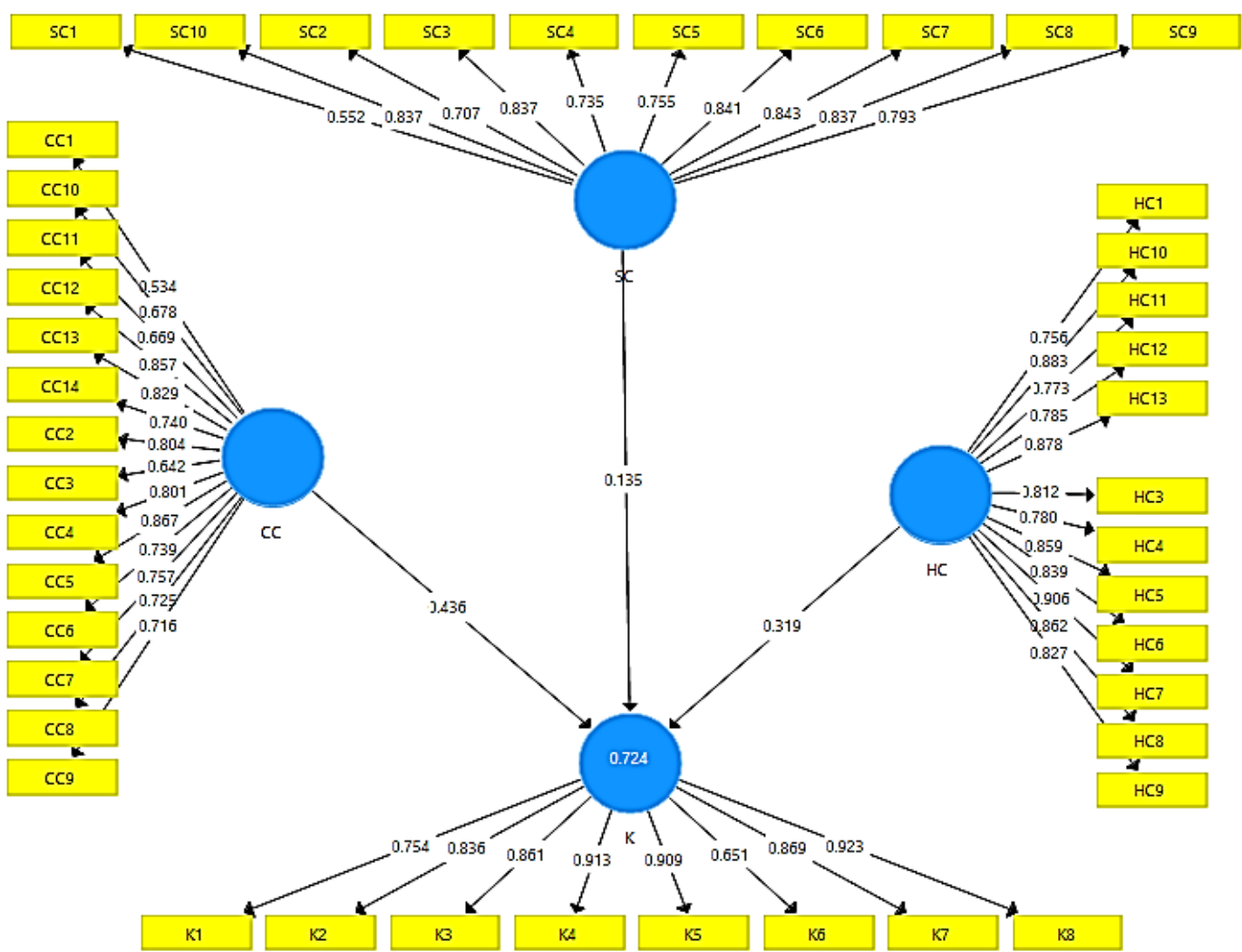

Figure 3. Smart PLS-Algorithm Test

Based on the results of the outer model Figure 3, all indicators already have an outer loading value $>0.50$, so the 
indicators, namely the variables of structural capital, human capital, customer capital, and performance are said to be valid. Table 1 showed the processed results of construct reliability and validity.

Table 1. Construct Reliability and Validity

\begin{tabular}{cccc}
\hline & Cronbach's Alpha & Composite Reliability & Average Variance Extracted (AVE) \\
\hline HC & 0,937 & 0,945 & 0,555 \\
\hline SC & 0,940 & 0,952 & 0,713 \\
\hline RC & 0,959 & 0,964 & 0,691 \\
\hline $\mathbf{K}$ & 0,926 & 0,938 & 0,606 \\
\hline
\end{tabular}

Based on the results as shown in Table 2, all components are declared reliable and valid. It can be seen from the Cronbach's Alpha value above 0.7. The Composite Reliability value is above 0.7 and the AVE value is above 0.5 . The coefficient of determination $r$ square shows that the variables human capital, structure capital, and relational (customer) capital can explain the financial performance variable of 0.707 or $70.7 \%$ so that the rest can be explained by other variables of $29.3 \%$. The results of hypothesis testing were obtained from bootstrapping testing using the Smart PLS 3.0 software. The test results are presented in Figure 4.

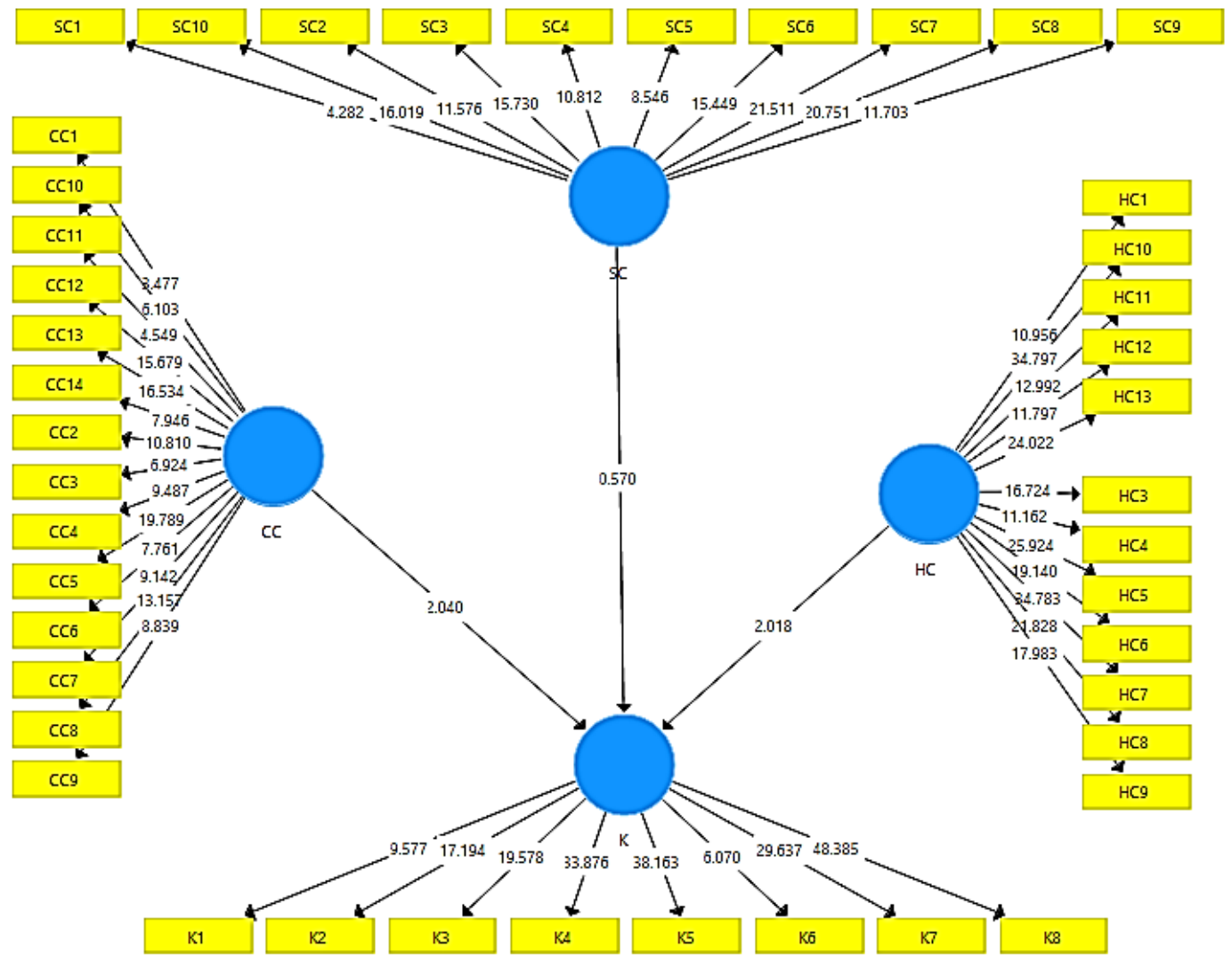

Figure 4. Smartpls- Bootstrapping Test

Exogenous variables were declared significant on the endogenous variables if the results of $t$ statistics $>t$ table 1.96 $(\mathrm{Sig}=5 \%)$. The results of the $\mathrm{t}$-statistics of each variable can be seen in Table 2 .

Table 2. Hypothesis Testing Results

\begin{tabular}{cccccc}
\hline & $\begin{array}{c}\text { Original Sample } \\
(\mathbf{O})\end{array}$ & $\begin{array}{c}\text { Sample Mean } \\
(\mathbf{M})\end{array}$ & $\begin{array}{c}\text { Standard Deviation } \\
(\text { STDEV })\end{array}$ & $\begin{array}{c}\text { T Statistics } \\
(\mid \mathbf{O} / \text { STDEV })\end{array}$ & P Values \\
\hline $\mathbf{H C}-\mathbf{F P}$ & 0,319 & 0,331 & 0,158 & 2,018 & 0,044 \\
\hline $\mathbf{S C}-\mathbf{F P}$ & 0,135 & 0,124 & 0,236 & 0,570 & 0,569 \\
\hline $\mathbf{C C}->$ FP & 0,436 & 0,439 & 0,214 & 2,040 & 0,042 \\
\hline
\end{tabular}


Based on Table 2, the t-statistic value of the human capital variable on financial performance is 2.018 which is greater than the t-table value of 1.96 , so it can be concluded that human capital has an effect on financial performance so that Hypothesis 1 is statistically supported. Human capital is generally seen as a critical component of intellectual capital and a key driver of organizational performance because it is based on competence (education, professional skills, knowledge), attitudes (motivation, leadership, behavior patterns), and intellectual agility (innovation, creativity, flexibility, ability to adapt $[15,45$, $48,50]$. Human capital is the main determinant of SME (small medium enterprise) performance compared to structural capital and relational capital [8]. This is because small and medium enterprises are constrained by size and funds to make large investments in external resources [51]. Therefore, the internal knowledge possessed by MSME managers and employees, in this case, human capital, must be managed and used effectively and efficiently so that MSMEs can maintain their success. Human capital in MSMEs needs to be continuously improved through education, training, and development programs.

The t-value of the structural capital on financial performance is 0.108 smaller than the t-table value of 1.96 , so it can be concluded that the Structural Capital hypothesis affecting performance is not statistically supported. Structural capital in the framework of the organization and includes all non-human knowledge contained in systems, procedures, databases, networks, process manuals, and so on. Several studies have shown an interaction between the components of intellectual capital. Intellectual capital is a construct with several dimensions that cannot be developed separately but has a strong bond. The interaction between Human Capital and Structural Capital has been proven in several studies so that investment in human capital can result in a significant increase in structural capital which in turn affects performance [52]. Intellectual capital can improve business performance, but it is up to management to encourage, develop, and utilize this intellectual capital to achieve the desired results. Bontis [48]; Bontis [15] shows that knowledge that remains only in the company's human capital and is not applied to organizational knowledge will not have a positive impact on business performance. For this reason, the influence of structural capital on financial performance can be said to depend on the management (human capital) of the organization to apply the knowledge possessed into organizational knowledge of structural capital.

The t-statistic value of relational (customer) capital on financial performance is 2.040 which is greater than the t-table value of 1.96 , so it can be concluded that the hypothesis of Relational Capital affects MSME financial performance is statistically supported. The relationship that exists between the organization and its partners can improve the financial performance of the organization through cost reduction and increasing market share. Consumers are the biggest component of company stakeholders who are the main determinants of the company's revenue. Therefore, strong relationships with consumers and other stakeholders will improve the financial performance of SMEs.

The test results in this study also show that relational capital has the highest p-value, so it can be stated that relational capital has the greatest influence on the financial performance of MSMEs compared to other components of intellectual capital. However, the difference between the p-value and the human capital component is very small. MSMEs with limited funds and tangible assets must manage and use their human and relational capital effectively and efficiently to improve MSME financial performance.

Intellectual capital is a concern in various fields such as management, information technology, sociology, and accounting. The importance of intellectual capital (IC) is caused by 4 (four) factors, namely the revolution in information technology, the importance of knowledge and knowledge-based business, activity patterns, and the emergence of innovation as a determining pattern, main competitive advantage.

In the era of globalization and rapid technological change, the role of micro and small enterprises, and medium-sized enterprises (MSMEs) in encouraging economic development and employment is very important even though MSMEs are often constrained by the problem of limited resources. Based on data from the Central Statistics Agency and the Ministry of Cooperatives and MSMEs (Kemenkop) the number of MSMEs reaches $98 \%$ and is able to absorb $96 \%$ of the workforce. With this amount, MSMEs can makes up $60 \%$ of the GDP. So far, the existence of MSMEs in Indonesia has been a driving factor in the creation of national economic development.

Therefore, as a major player in the country's economy, MSMEs are urged to be more dynamic and competent in facing challenges in today's knowledge-based economy. The failure of MSMEs to adapt to globalization and rapid technological changes can result in the failure of MSME operations in only the initial 5 years of operation. The development of a knowledge-based economy requires MSMEs to apply intellectual capital, namely human capital, structural capital, and relational capital, in order to compete in a dynamic business environment. Intellectual capital is seen as a resource that is able to provide a competitive advantage for MSMEs because the tangible capital owned by MSMEs is smaller than that owned by large-scale businesses. Therefore, intellectual capital as intangible capital is able to create a competitive advantage for MSMEs which further boosts organizational performance because these resources are difficult to duplicate, even seen as a strategic resource. The main function of intellectual capital is to create value-added products and services, through proactive management that 
positively affects business performance.

Several studies have been conducted related to intellectual capital in large companies and publications in the capital market. These studies provide empirical evidence of the effect of intellectual capital utilization on firm performance [53-55]. Several studies have also been conducted regarding the influence of the use of intellectual capital on the performance of small medium enterprises. The results of these studies provide empirical support for the influence of intellectual capital on company performance through increasing competitive advantage and the ability to innovate.

\section{Conclusions and Suggestions}

The results of this study provide empirical evidence of the influence of intellectual capital components, namely Human Capital and Relational Capital on the financial performance of MSMEs. These results provide additional empirical evidence for studies on the importance of intellectual capital on the financial performance of SMEs in particular with the context of SMEs in Papua that has not been studied. Thus, these results contribute to the development of theories on intellectual capital in SMEs. In this study, the effect of structural capital components on financial performance is not supported empirically. Further research needs to be done regarding the effect of structural capital interaction with other components of intellectual capital to improve MSME financial performance.

Of course, this research cannot be separated from its limitations, one of which is that the number of samples is quite small because some questionnaires that have been distributed are not all returned by the respondents. In addition, the concept of intellectual capital is quite complex so that it involves the subjectivity of respondents' perceptions. Suggestions for further research are that the number of respondents should be increased, the research location should be expanded and other components of intellectual capital should be tested to add empirical support for theory development.

\section{REFERENCES}

[1] Whiting R. H., Miller J. C, "Voluntary Disclosure of Intellectual Capital in New Zealand Annual Reports and the 'Hidden Value',' Journal of HRCA: Human Resource Costing \& Accounting, vol. 12, no. 1, pp. 26, 2008.

[2] Kianto A., Ritala P., Spender J. C., Vanhala M, "The Interaction of Intellectual Capital Assets and Knowledge Management Practices in Organizational Value Creation," Journal of Intellectual Capital, vol. 15, no. 3, pp. 362-375, 2014.
[3] Chahal H., Bakshi P, "Effect of Intellectual Capital on Competitive Advantage and Business Performance: Role of Innovation and Learning Culture," International Journal of Learning and Intellectual Capital, vol. 11, no. 1, pp. 52-70, 2014.

[4] Schiuma G., Lerro A, "Intellectual Capital and Company's Performance Improvement," Measuring Business Excellence, vol. 12, no. 2, pp. 3-9, 2008. DOI: $10.1108 / 13683040810881153$.

[5] Zéghal D., Maaloul A, "Analysing Value Added as an Indicator of Intellectual Capital and its Consequences on Company Performance," Journal of Intellectual Capital, vol. 11, no. 1, pp. 39-60, 2010.

[6] Tantra A, "Factors Affecting Intellectual Capital Disclosure and Company Value," Arthatama, vol. 2, no. 1, pp. 1-14, 2018.

[7] CIMA Annual Review, "The Power of Financial Management in Business Innovation," CIMA Global, Retrieved from: http://www.cimaglobal.com/documents/i mporteddocuments/cima ann-report.pdf.pdf, 2004 (access ed 23 sept, 2021)

[8] Daou A., Karuranga E., Su Z, "Towards a Better Understanding of Intellectual Capital in Mexican SMEs," Journal of Intellectual Capital, vol. 15, no. 2, pp. 316-332, 2014.

[9] Barney J. B, "The Resource-Based Theory of the Firm," Organization Science, vol. 7, no. 5, pp. 469-469, 1996.

[10] Barney J. B., Zajac E. J, "Competitive Organizational Behavior: Toward an Organizationally - Based Theory of Competitive Advantage," Strategic Management Journal, vol. 15, no. S1, pp. 5-9, 1994.

[11] Das T. K., Teng B. S, "A Resource-Based Theory of Strategic Alliances," Journal of management, vol. 26, no. 1, pp. 31-61, 2000.

[12] Peteraf M. A, "The Cornerstones of Competitive Advantage: A Resource - Based View," Strategic Management Journal, vol. 14, no. 3, pp. 179-191, 1993.

[13] Bridoux F, “A Resource-Based Approach to Performance and Competition: An Overview of the Connections Between Resources and Competition," Luvain, Belgium Institut et de Gestion, Universite Catholique de Louvain, vol. 2, no. 1, 2004, pp. 1-21.

[14] Galbraith J. K, "Intellectual Capital," New York, John Wiley \& Sons, 1969.

[15] Bontis N., Keow W. C. C., Richardson S, "Intellectual Capital and Business Performance in Malaysian industries," Journal of Intellectual Capital, vol. 1, no. 1, pp. 85-100, 2000 .

[16] Marqués D. P., Simón F. J. G., Carañana C. D, “The Effect of Innovation on Intellectual Capital: An Empirical Evaluation in the Biotechnology and Telecommunications Industries," International Journal of Innovation Management, vol. 10, no. 1, pp. 89-112, 2006.

[17] Cuganesan S, "Intellectual Capital-in-Action and Value Creation: A Case Study of Knowledge Transformations in an Innovation Project," Journal of Intellectual Capital, vol. 6, no. 3, pp. 357-373, 2005. 
[18] Nupus H., Ichwanudin W, "Business Network Accessibility, Customer Relationship Management and Shared Value Creation on Family Business Performance," Research Horizon, vol. 1, no. 4, 2021.

[19] Khalique M., Nassir Shaari J. A., Isa A. H. B. M, "Intellectual Capital and its Major Components," International Journal of Current Research, vol. 3, no. 6, pp. 343, 2011.

[20] Seemann P., DeLong D., Stucky S., Guthrie E, "Building Intangible Assets: A Strategic Framework for Investing in Intellectual Capital,” Knowledge management: Classic and contemporary works, London, The MIT Press, 2000, pp. 85-98.

[21] Kong C. W. E, "Human Capital, Structural Capital and Relational Capital: Which Comes First in Non-Profit Organizations?" In McMaster World Congress, Canada, MacMaster World Congress, 2003, pp. 1-16.

[22] Nerdrum L., Erikson T, "Intellectual Capital: A Human Capital Perspective," Journal of Intellectual Capital, vol. 2, no. 2, pp. 127-135, 2001.

[23] Bontis N., Fitz-enz J, "Intellectual Capital ROI: A Causal Map of Human Capital Antecedents and Consequents," Journal of Intellectual Capital, vol. 3, no. 3, pp. 223-247, 2002.

[24] Teece D. J, "Managing Intellectual Capital: Organizational, Strategic, and Policy Dimensions," Oxford, OUP Oxford, 2000.

[25] Martín-de-Castro G., Delgado-Verde M., López-Sáez P., Navas-López J. E, "Towards 'an Intellectual Capital-Based View of the Firm': Origins and Nature," Journal of Business Ethics, vol. 98, no. 4, pp. 649-662, 2011.

[26] De Leaniz P. M. G., Del Bosque I. R, “Intellectual Capital and Relational Capital: The Role of Sustainability in Developing Corporate Reputation," Intangible Capital, vol. 9, no. 1, pp. 262-280, 2013.

[27] Yaseen S. G., Dajani D., Hasan Y, "The Impact of Intellectual Capital on the Competitive Advantage: Applied Study in Jordanian Telecommunication Companies," Computers in Human Behavior, vol. 62, pp. 168-175, 2016.

[28] Saint-Onge H, "Tacit Knowledge: The Key to the Strategic Alignment of Intellectual Capital," Strategy \& Leadership, vol. 24, no. 2, pp. 10-15, 1996.

[29] Edvinsson L., Malone M. S, "Intellectual Capital: Realizing Your Company's True Value by Finding Its Hidden Brainpower," New York, HarperBusiness, 1997.

[30] Cegarra-Navarro J. G., Dewhurst F, "Linking Organizational Learning and Customer Capital Through an Ambidexterity Context: An Empirical Investigation in SMEs," The International Journal of Human Resource Management, vol. 18, no. 10, pp. 1720-1735, 2007.

[31] Wahyuni S., Praninta A, "The Influence of Brand Equity and Service Quality on Purchase Decisions on Garuda Indonesia Airline Services," Research Horizon, vol. 1, no. 1, pp. 28-38, 2021.

[32] Marr B., Schiuma G, "Business Performance Measurement - Past, Present and Future," Management Decision, vol. 41, no. 8, pp. 680-687, 2003.
[33] Brudan A, "Rediscovering Performance Management: Systems, Learning and Integration," Measuring Business Excellence, vol. 14, no. 1, pp. 109-123, 2010.

[34] Popova V., Sharpanskykh A, "Modeling Organizational Performance Indicators," Information Systems, vol. 35, no. 4, pp. 505-527, 2010.

[35] Osmani F., Maliqi G, "Performance Management, its Assessment and Importance," Procedia-Social and Behavioral Sciences, vol. 41, pp. 434-441, 2012.

[36] Ployhart R. E., Van Iddekinge C. H., MacKenzie Jr W. I, "Acquiring and Developing Human Capital in Service Contexts: The Interconnectedness of Human Capital Resources," Academy of Management Journal, vol. 54, no. 2, pp. 353-368, 2011.

[37] Goldin C. D, "Human Capital," (In Handbook of Cliometrics, ed), Claude Diebolt and Michael Haupert, Heidelberg, Springer Verlag, 2016, pp. 55-86.

[38] Soetjipto N., Kurniawan G., Sulastri, Riswanto A, "The Influence of Employee Discipline, Learning and Supervision on the Service Performance of Public Works in Bina Marga Office of Ponorogo Regency," Research Horizon, vol. 1, no. 4, 2021.

[39] Chidi C. O., Shadare O. A, "Managing Human Capital Development in Small and Medium-Sized Enterprises for Sustainable National Development in Nigeria," International Journal of Management \& Information Systems (IJMIS), vol. 15, no. 2, pp. 95-104, 2011.

[40] Benevene P., Cortini M, "Interaction Between Structural Capital and Human Capital in Italian NPOs: Leadership, Organizational Culture and Human Resource Management," Journal of Intellectual Capital, vol. 11, no. 2, pp. 123-139, 2010.

[41] Hejazi R., Ghanbari M., Alipour M, "Intellectual, Human and Structural Capital Effects on Firm Performance as Measured by Tobin's Q," Knowledge and Process Management, vol. 23, no. 4, pp. 259-273, 2016.

[42] Zangoueinezhad A., Moshabaki A, "The role of Structural Capital on Competitive Intelligence," Industrial Management \& Data Systems, vol. 109, no. 2, pp. 262-280, 2009.

[43] Fakhimuddin M., Khasanah U., Trimiyati R, "Database Management System in Accounting: Assessing the Role of Internet Service Communication of Accounting System Information," Research Horizon, vol. 1, no. 3, pp. 100-105, 2021.

[44] Shahzad F., Luqman R. A., Khan A. R., Shabbir L, "Impact of Organizational Culture on Organizational Performance: An Overview," Interdisciplinary Journal of Contemporary Research in Business, vol. 3, no. 9, pp. 975-985, 2012.

[45] Pudjiarti E. S., Hutomo P. T. P, "The Critical Role of Effective Organizational Learning to Improve Firm's Innovation and Performance in a Market Turbulence Condition," International Journal of Innovation Science, vol. 12, no. 3, pp. 237-254, 2020.

[46] Laitamäki J., Kordupleski R, "Building and Deploying Profitable Growth Strategies Based on the Waterfall of Customer Value Added," European Management Journal, vol. 15, no. 2, pp. 158-166, 1997. 
[47] Sekaran U, "Research Methods for Business: A Skill-Building Approach," Wiley Series in Management, 2003.

[48] Bontis N, "Intellectual Capital Disclosure in Canadian Corporations," Journal of Human Resource Costing \& Accounting, vol. 7, no. 1/2, pp. 9-20, 2003.

[49] Mansyur M, "Marketing Opportunities for Bank Syariah Mandiri e-Banking Services as a Payment Method," Research Horizon, vol. 1, no. 2, pp. 71-80, 2021.

[50] Riswanto A, “Competitive Intensity, Innovation Capability and Dynamic Marketing Capabilities," Research Horizon, vol. 1, no. 1, pp. 7-15, 2021.

[51] Deni A., Riswandi R., Sobar A., Hamidi D. Z., Permadi I, "The Effect of Product Turnover on Company Performance of SMEs," Research Horizon, vol. 1, no. 3, pp. 115-119, 2021.
[52] Ardiansari A., Ridloah S., Pangestuti I. R. D., Indriyani P "The Influence of Intellectual Capital on the Company's Financial Performance and Market Value," Universal Journal of Accounting and Finance, vol. 9, no. 2, pp. 217 225, 2021. DOI: 10.13189/ujaf.2021.090211

[53] Chen M. C., Cheng S. J., Hwang Y, "An Empirical Investigation of the Relationship Between Intellectual Capital and Firms' Market Value and Financial Performance," Journal of Intellectual Capital, vol. 6, no. 2, pp. 159-176, 2005.

[54] Clarke M., Seng D., Whiting R. H, "Intellectual Capital and Firm Performance in Australia," Journal of Intellectual Capital, vol. 12, no. 4, pp. 505-530, 2011.

[55] Vafaei A., Taylor D., Ahmed K, "The Value Relevance of Intellectual Capital Disclosures," Journal of Intellectual Capital, vol. 12, no. 3, pp. 407-429, 2011. 